\title{
Management Intellectual Capital and its Role in Achieving Competitive Advantages at Jordnanian Private Universities
}

\author{
Khulah Qassas $^{1}$ \& Ahmad Areıqat ${ }^{1}$ \\ ${ }^{1}$ Business Management, Al-Ahliyya Amman University, Jordan \\ Correspondence: Ahmad Areıqat Professor of Business Management, Al-Ahliyya Amman University, Jordan.
}

Received: October 19, 2020

Accepted: November 1, 2020

Online Published: November 26, 2020

doi:10.5430/ijhe.v10n2p92

URL: https://doi.org/10.5430/ijhe.v10n2p92

\begin{abstract}
This study aimed to identify the role of intellectual capital (human capital, structural capital, and relational capital) in achieving competitive advantage (quality of education, flexible and responsive, and innovation) at Al-Ahliyya Amman University, to achieve these goals, the researcher used the descriptive and analytical approach. The study tool in collecting information and data was a questionnaire distributed to all the university's employees, who numbered (630) individuals. The data, the study questions and hypotheses were analyzed through the Statistical Package for Social Sciences (SPSS).

The study concluded some results, the most important is: The structural capital and its components (combined) have a statistically significant effect on achieving competitive advantage. The researcher recommend the necessity of dealing with intellectual capital as a major and strategic resource for the university and considering it the real wealth that guarantees universities the ability to adapt to achieve a competitive advantage in them.
\end{abstract}

Keywords: intellectual capital, competitive advantage, Jordanian private universities, Al-Ahliyya Amman University.

\section{Introduction}

In a rapidly changing world, knowledge is the best tool to predict future needs, and to move forward in societies towards building a sustainable knowledge economy to ensure the well-being and happiness of individuals, relying mainly on people with practical minds, knowledge, and creative and innovative ideas who contribute to the survival and growth of the institution. The real value of this institution is magnified in its the distinct intellectual capital, able to provide opinions and ideas that improve performance, develop products and services, and increase competitiveness (Januškaite \& Užiene, 2018).

In a contemplative reading of the World Competitiveness Report until mid-year 2020 issued by the World Economic Forum, which shows a general ranking of the most competitive countries, it is noted that the following countries topped the ranking, as Singapore came first, followed by Denmark, and Switzerland Third, despite the fact that these countries do not possess seem material wealth and resources compared to the great countries such as the United States, which ranked tenth, the United Kingdom ranked (19), while the United Arab Emirates ranked ninth, and the State of Qatar ranked (14), which indicates that these countries that led the ranking would not have achieved that except by their ability to employ it's the human energies holdings and effective relationships that together formed their intellectual capital.

This is confirmed by Professor Arturo Bris, executive chairman of the Center for Global Competitiveness and Professor of Finance, and the benefit of small economies comes from their ability to employ their intellectual capital in enhancing their competitiveness (IMD, 2020).

Therefore, intellectual capital has become the real and effective capital of institutions as it is the main pillar that plays a central role in the process of innovation, renewal and competitiveness, and thus it is able to convert knowledge into value and then into a competitive advantage, so it has become one of the requirements of the current work environment is to focus on how Developing its intellectual capital to achieve elements that excel its competitors, whether it is in terms of quality of performance, or flexibility in rapid response to sudden changes that may occur (Scafarto, et al., 2016). 


\section{The Study Problem}

Those responsible within the private Jordanian universities to move forward in the university's career in order to enable to keep pace with modern developments of higher education trends, and to face the urgent challenges, causing a transformation from education at the university to integrated or distance education, especially since teaching via the Internet is not the new method in some good universities, and in order to keep pace with this development, it has become imperative for the university to use what it has of human capital and relationships through which it can achieve the desired progress and desired goals.

This make it in a prominent position among its competitors from other universities. In order for Jordanian universities to achieve competitiveness, they must play their real role in building a university system characterized by modern diversity in study plans and programs, management style and quality systems followed, and create rehabilitation programs in line with environmental developments, relying on their internal resources or what is known as intellectual capital for promoting and strengthening its capabilities and competitive advantages in order to achieve the advancement in its educational and learning level to the best administrative and academic levels, from here the idea of interest in intellectual capital and its management at Jordanian private universities to help them achieve the desired distinction.

From this standpoint, the study problem is taken shape by answering the following questions:

\section{The Main Question}

What is the role of intellectual capital management in achieving competitive advantage at Al-Ahliyya Amman University?

From the main question above, we divide the following questions:

1) What is the role of human capital in achieving competitive advantage in Al-Ahliyya Amman University?

2) What is the role of structural capital in achieving competitive advantage in Al-Ahliyya Amman University?

3) What is the role of relational capital in achieving competitive advantage in Al-Ahliyya Amman University?

4) What are the respondent interviewees' perceptions of the level of achieving competitive advantage at AlAhliyya Amman University?

\section{Objectives of the Study}

This study aims to identify the management of intellectual capital with its components and its role in achieving competitive advantage in private Jordanian universities, and to achieve this goal, many of the sub-objectives have been formulated as follows:

1) Identify the components of intellectual capital at Al-Ahliyya Amman University.

2) Identifying the level of achieving competitive advantage in Al-Ahliyya Amman University.

3) Explain the nature of the influential relationships between the study variables.

4) Presenting proposals and recommendations for officials at Al-Ahliyya Amman University to enhance the role that intellectual capital plays with its various components in achieving institutional excellence at Al-Ahliyya Amman University.

\section{The Significance of the Study}

The sudden, recent and accelerating developments and the emergence of formidable challenges may show the extent to which private universities in Jordan are prepared or not to use creative and innovative strategies through which they can face these challenges and achieve their competitive advantage through the intellectual capital it possess in the diversity of its components. This study shows the following:

1) The study dealt with a vital sector important for development in Jordanian society, which is educational institutions.

2) Highlighting on one of the approaches to modern management thought, which is the management of intellectual capital and its role in achieving a competitive advantage in Jordanian universities.

3) Developing and improving business and services provided by Jordanian private universities for scholars, researchers and the local community, and enhancing the competitive advantages that universities may achieve.

4) Providing efficient ways to manage intellectual capital in private Jordanian universities in a way that achieves maximum benefit from it. 
5) Opening the fields to researchers to view models of intellectual capital management in private Jordanian universities.

\section{Theoretical Framework and Literature Review}

\subsection{Intellectual Capital}

Contemporary trends in modern management are moving towards the features of a new topic that is concerned with intellectual assets more than physical assets because the addition and magnification in physical assets is due to the availability of intellectual assets. This new topic is Intellectual Capital, which began to spread with the 1990s, where intellectual capital was a preoccupation for scholars, academic and business researches, who tried to find a way to measure it and make it part of the budget of their organizations despite the difficulty of measuring it (Kozera-Kowalska \& Baum, 2018).

Ralph Stayer, director of the John Sonville Food Company, was the first to give the phrase "intellectual capital" in the year 1990, when Steyr said, not long ago, natural resources were the most important source of national wealth and the most important assets of companies, and then he became the capital in the form of cash and assets such as machinery and factories is what is important, but now it has been replaced by the mental capacity represented by intellectual capital (Kianto et al., 2013).

Intellectual capital has now become the most important source for maximizing other assets in institutions and organizations because it is a catalyst in increasing material returns and achieve construction (Al-Shimi, 2011) (Areiqat, Hamdan, Zamil, Horani, \& Al-Khoury, 2020).

Intellectual capital represents the knowledge and innovative ideas that the university possesses and which contributes to its survival and development. Therefore, the university realizes that its real value increases in the distinct intellectual capital it possesses, capable of presenting opinions and ideas that improve performance and develop the services that it conveyed and which contribute to increasing Competitive capabilities. Thus, intellectual capital is the main source of competitive advantage, and the factor affecting the success of institutional performance, and it strengthens the competitive position of the organization by providing new educational products and services at low costs (Gogan \& Duran, 2014) (Areiqat, Zamil, Fathi, \& Abushaar, 2020).

\subsection{Intellectual Capital Components}

Most researchers agree that intellectual capital consists of three basic components (Elena, 2015):

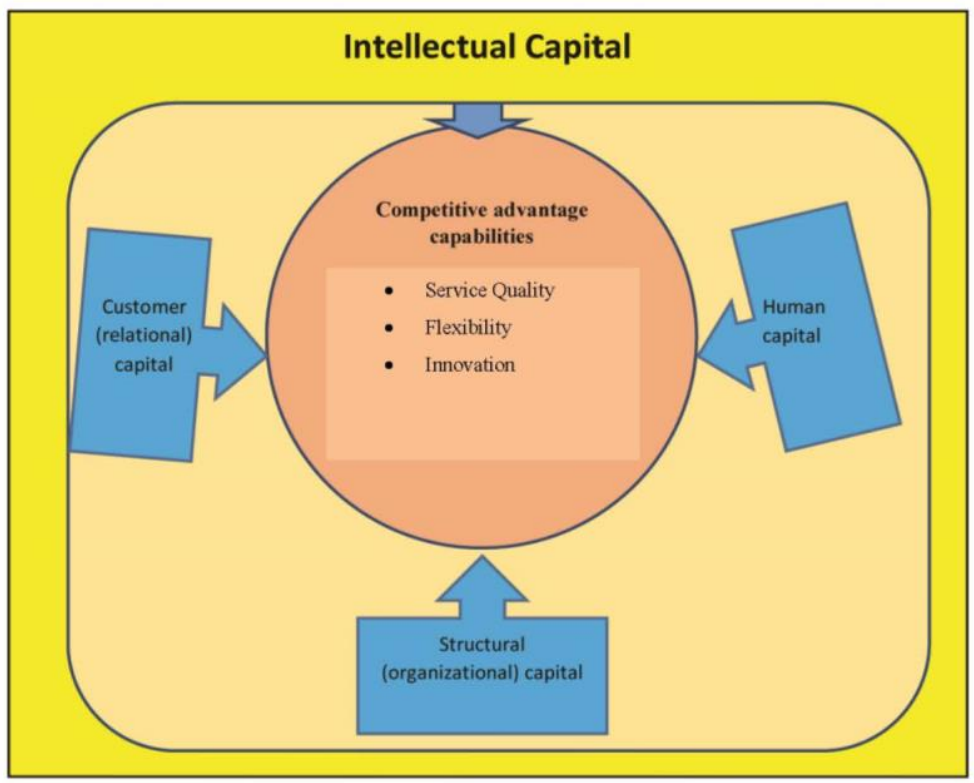

Figure 1. Study model (Elena, 2015)

Human Capital: It is the totality of the knowledge that individuals acquire during their working life and the characteristics, skills and abilities owned by Personnel possess that can be directed to achieve the goals of the organization.

The human resources represented by all the employees of the organization of various categories, levels and 
specializations are the real pillar on which the modern organization is based.

In view of the paramount importance of human resources and their ability to contribute positively to achieving the goals of the organization, modern management attachs commensurate attention to human resources issues through an attempt to find a balance between the objectives of the organization and the goals of individuals and between the cost and benefit in dealing with individuals.

The modern administration launch from its interest in human development from a sound scientific belief that the human being has mental energies and capabilities that exceed what is often exploited or benefited.

That the maximum utilization of that mental strength is the real source of excellence for organizations and their ability to achieve impressive, unconventional achievements. Therefore, the main focus of modern management thinking is to give the opportunity to human resources and pay attention to them in order to be able to make these resources feature an effective strategy at the level of organizations.

Therefore, we find that human capital is inexhaustible, but is growing by the amount of increase in skills, experience and knowledge, and that its productivity curve is in a direct, upward relationship towards the curve of creative and innovative experiences and capabilities, and that it is subject to development and renewal with the changes of the times. (Al Zahrani, Zamil, Areiqat, \& Alsalhi, 2012).

\subsection{Structural Capital}

It is the ability of the organization to transfer, publish and employ the knowledge, skills and expertise available to the workers of the organization to the actual fact, and this deployment and staffing are done through the presence of an appropriate organizational structure and clear powers and responsibilities, it has competence in the application of knowledge, skill and experience in the organization. Structural capital is represented in culture, organizational models, processes, procedures, and distribution channels (Margareta, 2015) (Areiqat, Abdelhadi, Al-Bazaieh, and Abu Rumman, 2019) (Areiqat, 2019).

\subsection{Relational Capital}

It is one of the components of intellectual capital, and it is represented by inherent values in the organization's relations with its external environment, such as market relations, power relations and cooperation that arise between organizations, institutions and people, and which comes from a national sense of belonging and evolving capacity of exemplary cooperation between culturally persons and institutions.

Relational dependency may be vertical or horizontal, either up or down, and the formation of various types of cooperation mechanisms in various ecosystems, such as strategic alliances, which are intended to replace cooperation with competition that may lead to the exit of one of the parties from the market. The strategic alliance lies in the creativity of cooperation. The strategic alliance lies in the spirit of cooperation and development that is based on a relationship of mutual trust and allows to reach specific goals by mutual agreement (Areiqat and Jaradat, 2012)

Alliances differ by type of relationship, a degree rationality, understanding, the size of risks, information, interests and the circumstances of the surrounding environment (Magdalena, 2020).

\section{Competitive Advantage}

The concept of competitive advantage has received great attention in recent years at the local and global level, as the competitive advantage is the essence of the organization's performance. Therefore, it has been directed to work on the quality of its services and satisfy the desires of its customers and progress to achieve the competitive advantage. (Alheet, Adwan, Areiqat, Zamil \& Saleh, 2020). The researcher likens the competitive advantages - to some extent- to the reserve stock that is used to meet any urgent vagaries in the increase in the demand for a particular good or service, so the organization is ready to overcome this accidental increase steadily and successfully.

The organization's possession of a competitive advantage enhances its competitiveness, and thus the alternatives available to it increase in achieving spread and expand in provision of services, as well as relative certainty and stability and lengthening its life span. On the other hand, the competitive advantage has benefits in the organizations' resilience in the face of sudden changes such as economic fluctuations, or the entry of new strong competitors. The organization's possession of competitive advantages enhances its negotiating capacity with suppliers as well as enables it to provide its services or products with relative stability (Meihami \& Meihami, 2014).

Business organizations can achieve competitive advantage by best use of the available means and organizational, material and financial resources, in addition to the capabilities, knowledge, competencies and other capabilities of the organization, which enable it to design and implement its competitive strategies. 
Competition has become the modern-day language and the focus of everyone's attention, individuals and institutions alike, as it is the driving factor through which everyone's steps are controlled and motivated to work with more generosity, creativity and innovation, to achieve a measure of competitive advantage or superiority over their peers and competitors in order to achieve the highest levels of return or Profitability (Akben, 2016).

Porter (1985) identifies two methods through which a university can achieve a competitive advantage over its competitors: the price advantage, this advantage is achieved when the university offers the same products and services offered by its competitors, but at a lower preferential price. As for the product or service advantage, it is achieved when the university provides better products and services than the products and services of competing universities. From Porter's point of view, strategic management should be concerned with building and maintaining competitive advantage, and here the human resources that the university possesses will have a profound effect on creating competitive advantage. (Areiqat, Hamdan, Zamil, and Aldabbagh, 2020)

\section{Related Articles}

8.1 Raed et al., (2020). The Effect of Intellectual Capital on Competitive Advantage in the Jordanian Telecommunication Sector.

This paper sought to examine the effect of intellectual capital on competitive advantage in the Jordanian telecommunication sector. Indeed, intellectual capital is generally assumed to be an important aspect of the organization and one of the most conducive to innovative activity and unrestrained competition. The paper finds that the tripod of intellectual capital, namely, human capital, structural capital, and relational capital has a significant influence on achieving a competitive advantage. Among these three dimensions, relational capital is the most influential component in enhancing the competitive advantage. Considering these results, the research presented many recommendations for future research, the most important ones is implementing this study on other sectors, resort to multi-method of data collection, and the use of probability sampling techniques.

8.2 Saqer et al., (2019). The Impact of the Intellectual Capital of the University Administration in Achieving the Quality of Education.

The rational and entrepreneurial universities are working in the possession of an important resource, which is the intellectual capital, to reach the local and global leadership, Such study aims at stating the intellectual capital impact of the rational university administration in accomplishing its quality of education since the study population consisted of both public and private Jordanian University while the study sample reached to (45) faculty members were chosen randomly and were working in such Universities, a questionnaire has been designed and distributed on (45) faculty members of the study population, who were working in such Universities, for the purpose of achieving the study aims as well as the essential statistical exams have been conducted whereas the findings showed that there is an impact of the intellectual capital) for the rational University administration of the different kinds of the Universities (the humankind, the structural, and the relational in achieving its quality of education while the study recommendations revolve around the necessity of the Universities in identifying the intellectual capital and determining the practical means to preserve and improve it in order to guarantee its quality of education.

8.3 Magdalena (2020). Intellectual Capital: ISVA, the Alternative Way of Calculating Creating Value in Agricultural Entities-Case of Poland.

This paper describes the Intellectual Sources of Value Added (ISVA), an alternative method for analyzing the productivity of tangible and intangible inputs affecting the value-adding process in agricultural holdings. The reasons for developing the concept of that indicator were the imperfections found in the Value-Added Intellectual Coefficient (VAIC), a widely adopted method authored by A. Pulic. However, the index of efficiency of intellectual capital (VAIC), recognized as suitable for research purposes, demonstrates certain methodological imperfections, including the simultaneous use of resource- and flow-based values. In addition to certain relevant reservations, the above has other consequences, including the declining trend followed by the efficiency of working capital calculated using this formula. In a situation where working capital is observed to grow, this would mean that funds are irrationally invested in assets with a decreasing capacity to add value. This results in drawing a false picture of economic realities of agricultural holdings which, by nature, demonstrate a high share of physical asset consumption in total production costs. As another consequence, the calculated value of the indicator becomes unacceptable in the long run. The use of the ISVA indicator allowed the author to obtain homogeneous results in terms of methodology and confirming the regularities observed in practice. In addition, the research confirmed not only the fact that agricultural enterprises have intellectual capital resources, but also the high efficiency of their use, exceeding the efficiency of use of traditional 
ones. It also indicates the desirability of continuing research using measures that will enable the monitoring of intellectual capital and their use in agricultural enterprises.

\subsection{Aymen (2018). The Impact of Intellectual Capital on Business Organization.}

The main purpose of this research is to examine the components of intellectual capital and how intellectual capital affects business organizations. The study also examines how the intellectual capital items are accounted for in the financial statements. Literature review and theoretical framework are used in describing the three components of intellectual capital, how they are recognized in the financial statements of an entity and the impact that they have in the business organization. Secondary sources of data such as journals and books are used in the study to qualitatively analyze the impact that the intellectual capital has on the business organization. Results of the qualitative analysis indicate that intellectual capital impacts the business organization in various ways such as enhancing the competitive advantage, facilitating innovation, enhancing the competency of the employees and increasing the organizational performance. Financial managers could make use of this research to gain insights on the categories of intellectual capital including the intellectual capital items to be included in the financial statements and those that should not be included.

\subsection{Nazem et al., (2018). Intellectual Capital as a Core Competency for Competitive Advantage: A Case Study.}

This paper aimed to study intellectual capital as a core competency for competitive advantage at pharmaceutical companies in Jordan. To complete the study, a case study was instituted by analyzing the responses of the pharmaceutical companies; the data collected were analyzed with a statistical package. The study concluded some results, the most appearing were; pharmaceutical companies depend on intellectual capital at a high level, competitive advantage also high, and there is a significant statistical effect of intellectual capital on competitive advantage as a whole and on all its indicators (leadership, human recourse, innovation, processes, and financial excellence) at ( $\alpha \leq$ $0.05)$ Researchers recommend pharmaceutical companies management and staff to reinforce using intellectual capital at all levels and functions and use it as a main source for competitive advantage in all its areas.

8.6 Sungmin \& Youn (2020). Effects of Strategy Characteristics for Sustainable Competitive Advantage in Sharing Economy Businesses on Creating Shared Value and Performance.

This study aimed to identify strategy characteristics for sustainable competitive advantage in businesses utilizing the sharing economy (SE) and to investigate whether such strategy characteristics are related to creating shared value (CSV) and performance. A total of 631 participants who had used goods and services of SE businesses were selected as the unit of analysis in reference to the components of business-to-peer (B2P) and peer-to-peer (P2P) SE business models. Reliability, validity, and goodness-of-fit tests and path analysis were performed using SPSS and AMOS statistical packages. The following results were obtained. First, regarding the relationship between strategy characteristics for sustainable competitive advantage and "social congruence," which is related to creating shared value, this variable was significantly influenced by "value network" in the B2P model and "strategic innovation" and "strategic resources" in the P2P model. Second, regarding relationship with the aforementioned strategy characteristics and "value of information sharing," the latter variable was significantly influenced by "moment of truth," "strategic innovation," and "value network" in the B2P model, and "moment of truth," "strategic resources," and "value network" in the P2P model. Third, regarding the relationship among variables related to CSV and their contribution to performance, "social value congruence" was affected by "value of information sharing," and these variables had significant effects on "value of participation" in both models. Only "value of participation" made a significant contribution to "performance.".

8.7 Matthew et al., (2020). Rethinking the Attributes for Competitive Advantage of Indigenous Construction Firms in Developing Countries: A Ghana Study.

Though studies in the past have advanced some attributes for competitive advantage in certain national contexts, little is known of the empirical studies that identify the principal attributes for competitive advantage of indigenous construction firms in developing countries to adduce empirical findings toward firms' competitive advantage policy. This study identifies the principal and sub attributes for competitive advantage of indigenous construction firms in developing countries using Ghana as a case study. The use of principal component analysis, varimax rotation in data analysis aided in reducing the large set of attributes to four principal components. Using a questionnaire survey, 667 respondents were invited to rate 21 attributes identified from literature and structured interview based on their knowledge and/or experience. Correlations between the 21 variables showed that four principal components underlay the attributes for competitive advantage of indigenous construction firms: firms' internal factors, firm-industry conditions, collaborations, and firm owners' competencies and influence. It was also revealed that 4 out of the 21 
attributes were peculiar to Ghana only. Findings and recommendations of this study may be useful for industry stakeholders who are seeking innovative ways to enhance indigenous construction firms' competitive advantage, pedagogy, and curriculum review.

8.8 Asante \& Adu-Damoah (2018). The Impact of a Sustainable Competitive Advantage on A Firm's Performance: Empirical Evidence from Coca-Cola Ghana Limited.

Current organizations turn to many standard techniques to achieve competitive advantage, and if they are sustainable, then the organization benefits from the competitive advantage. As markets grow more saturated, only the organization with the highest sustainable competitive advantage will benefit the most. The primary objective of this study is to ascertain the impact of a sustainable competitive advantage on firm's performance using evidence from Coca-Cola Ghana limited. The population included employees of Coca-Cola Ghana Limited in the four main regional capital cities and affiliated stakeholders. The data collected from 356 respondents were analyzed with Smart PLS statistical software. The results from the Structural Equation Model (SEM) revealed that sustainable competitive advantage is positively related to organizational performance. Resources and competitive environment have a moderating effect on firm's strategy. It also established that resources and competitive environment are directly related to firm's performance. Finally, it confirmed the relationship between human resource strategy and firm's performance as positively related. The study concludes that the effects of the firm's strategy, resources and competitive environment and human resource strategies on sustainable competitive advantage are undeniable and they have numerous impacts on firms' performance.

\section{Research Methodology}

A descriptive and analytical approach was used, which studies the phenomenon in its dimensions and expresses it quantitatively and qualitatively to achieve the objectives of the research and reach specific results.

Study population:

The study population consists of all employees of Al-Ahliyya Amman University, whose number is (630) employees, administrative employees and academics (https://www.ammanu.edu.jo).

The study sample:

The sample is considered a part of the study population and was taken to accurately represent the community, and to achieve this, the researcher used the comprehensive survey by including all the items of the statistical community at Al-Ahliyya Amman University, which are (630) items (https://www.ammanu.edu.jo).

The Statistical Methods Used:

1) Percentages, frequencies, arithmetic mean, relative weight and arrangement for the purposes of knowing the frequency of a variable category in the demographic characteristics of the study sample and analyzing the items of the study variables.

2) Cronbach's Alpha test to find out the stability of the items of the questionnaire.

3) Pearson correlation coefficient to assess the linear relationship between social capital with its dimensions and its role in achieving organizational innovation.

4) Linear Regression test to study the effect of independent variables on the dependent variable and the main hypothesis.

5) (Durbin - Watson) test for the self-correlation of the study variables.

Table 1 . The stability values of the study instrument using Cronbach's Alpha

\begin{tabular}{ccccc}
\hline No & Study variables & $\begin{array}{c}\text { Number of } \\
\text { paragraphs }\end{array}$ & $\begin{array}{c}\text { paragraph } \\
\text { numbers }\end{array}$ & $\begin{array}{c}\text { Cronbach's } \\
\text { Alpha }\end{array}$ \\
\hline 1 & Human capital & 5 & $5-1$ & 0.992323 \\
2 & Structural capital & 5 & $10-6$ & 0.907 \\
3 & Relational capital & 5 & $15-11$ & 0.896 \\
4 & Dimension of quality education & 5 & $20-16$ & 0.913 \\
5 & The dimension of resilience & 5 & $25-21$ & 0.873 \\
6 & Innovation & 5 & $30-26$ & 0.890 \\
& Total & $\mathbf{3 0}$ & $\mathbf{3 0 - 1}$ & $\mathbf{0 . 9 0 9}$ \\
\hline
\end{tabular}


Table No. 1 shows that the Cronbach alpha coefficients fall between $(0.873-0.907)$ and this indicates that all the paragraphs of the study variables achieved the stability condition by exceeding them (0.700), which means that all the paragraphs of the questionnaire are stable, meaning that the stability of the resolution is high and statistically significant and thus The questionnaire, in its final form, can be distributed to the study population's (630) members, which makes the researcher sure of the validity of the questionnaire and its validity to analyze the data and answer the study questions.

Table 2. Demographic and functional characteristics of the study population

\begin{tabular}{lcc}
\hline Characteristics & Frequency & Percentage \\
\hline Gender & 385 & \\
$\quad$ Male & 245 & $61.4 \%$ \\
$\quad$ Female & $\mathbf{6 3 0}$ & $38.6 \%$ \\
Total & & $\mathbf{1 0 0 \%}$ \\
Age & 145 & \\
$\quad 30$ years and less & 201 & $23.0 \%$ \\
$\quad 31-40$ & 186 & $32.0 \%$ \\
$\quad 41-50$ & 98 & $29.5 \%$ \\
51 and more & $\mathbf{6 3 0}$ & $15.5 \%$ \\
Total & & $\mathbf{1 0 0 \%}$ \\
Educational Level & 242 & \\
$\quad$ Bachelor & 153 & $38.4 \%$ \\
$\quad$ Master & 235 & $24.3 \%$ \\
$\quad$ Doctoral & $\mathbf{6 3 0}$ & $37.3 \%$ \\
Total & & $\mathbf{1 0 0 \%}$ \\
Working Experience & 76 & \\
$\quad$ Less than 5 years & 190 & $12.0 \%$ \\
5-10 & 248 & $30.2 \%$ \\
$\quad 11-15$ & 116 & $39.4 \%$ \\
16 and more & $\mathbf{6 3 0}$ & $18.4 \%$ \\
Total & & $\mathbf{1 0 0 \%}$ \\
\hline
\end{tabular}

\section{Presentation and discussion of results:}

The first question: What is the role of human capital in achieving competitive advantage at Al-Ahliyya Amman University?

Table 3. The arithmetic mean, standard deviation, estimates of the study sample, and t-test for the human capital

\begin{tabular}{cccccccc}
\hline $\mathbf{N}$ & $\begin{array}{c}\text { Paragraphs of } \\
\text { independent variables }\end{array}$ & $\begin{array}{c}\text { Arithmetic } \\
\text { Mean }\end{array}$ & $\begin{array}{c}\text { Standard } \\
\text { Deviation }\end{array}$ & $\begin{array}{c}\text { The } \\
\text { relative } \\
\text { weight of } \\
\text { the sample } \\
\text { estimates }\end{array}$ & $\begin{array}{c}\text { t test } \\
\text { value }\end{array}$ & Sig. & Rank \\
\hline $1 \quad \begin{array}{l}\text { All university employees } \\
\text { have the knowledge } \\
\text { necessary to perform } \\
\text { their duties in the best } \\
\text { way possible. }\end{array}$ & 3.96 & 0.813 & $\% 79.2$ & 18.29 & 0.000 & 4 \\
2 & & & & & & & \\
$\begin{array}{l}\text { University employees } \\
\text { are keen to search for } \\
\text { and acquire knowledge } \\
\text { required in their field. }\end{array}$ & 3.81 & 0.864 & $\% 76.2$ & 16.33 & 0.000 & 5 \\
\hline
\end{tabular}


3 The university administration is keen to confirm the availability of the necessary skills and capabilities during 0.795 $\% 85.4$ $20.26 \quad 0.000$ 2 the attract and recruit operations.

4 The university has a sufficient number of scientifically and professionally qualified employees to perform the functional tasks assigned to them.

5 The practical and scientific experiences that the university employees possess contribute to providing excellent solutions to the problems they face.

Total

4.09

0.716

$\% 81.8$

$19.70 \quad 0.000$

Table 3 shows that the value of $t=19.70$ (T.Test) and the value of the calculated test significance reached $(0.000)$, which is a significant value indicating that there is a clear response to the field of human capital at the university and the relative weight of this field is equal to $(81.8 \%)$ and this result It indicates that the axis of human capital was at a high degree at Al-Ahliyya Amman University, and that the highest paragraph was No. (5) and obtained approval with a high degree with a relative weight $(86.4 \%)$ and a level of significance less than $(0.05)$ which provided for (Contributes to practical and scientific experiences It is owned by university employees in providing excellent solutions to the problems they face); Therefore, this paragraph is considered a statistical function, as are the rest of the paragraphs of this field.

The second question: What is the role of structural capital in achieving competitive advantage in Al-Ahliyya Amman University

Table 4. The arithmetic mean, standard deviation, estimates of the study sample, and t-test for the structural capital

\begin{tabular}{lllcllll}
\hline $\mathbf{N}$ & $\begin{array}{l}\text { Paragraphs of } \\
\text { independent variables } \\
\text { Structural capital }\end{array}$ & $\begin{array}{c}\text { Arithmetic } \\
\text { Mean }\end{array}$ & $\begin{array}{c}\text { Standard } \\
\text { Deviation }\end{array}$ & $\begin{array}{c}\text { Relative } \\
\text { weight of the } \\
\text { sample } \\
\text { estimates }\end{array}$ & $\begin{array}{c}\text { t test } \\
\text { value }\end{array}$ & Sig. & Rank \\
& $\begin{array}{l}\text { The university } \\
\text { administration is keen to } \\
\text { clarify the rules and } \\
\text { regulations for its } \\
\text { employees since joining } \\
\text { the work. }\end{array}$ & 4.17 & 1.03 & $\% 83.4$ & 14.09 & 0.000 & 2 \\
$\begin{array}{l}\text { The employee is } \\
\text { obligated to follow } \\
\text { reporting lines } \\
\text { according to the } \\
\text { university's } \\
\text { organizational structure. }\end{array}$ & 4.06 & 1.07 & $\% 81.2$ & 13.70 & 0.000 & 3 \\
$\begin{array}{l}\text { There is a specific job } \\
\text { description for the tasks, } \\
\text { duties, and } \\
\text { responsibilities required }\end{array}$ & 4.28 & 0.87 & $\% 85.6$ & 14.33 & 0.000 & 1 \\
\hline
\end{tabular}


of the university

employee.

The university has a procedures guide that

4 explains and defines the

$\% 77.4$

$11.93 \quad 0.000$

4

the work.

There are specific and

5 standardized models for

everyone who exercises

0.81

$\% 76.4$

$11.46 \quad 0.000$

5 the same function.

\section{Total}

4.04

0.74

\%80.8

$12.28 \quad 0.000$

Table 4 shows that the value of $\mathrm{t}=12.28$ ( $\mathrm{T}$ test) and the value of the calculated test significance was $($ sig $=0.000)$, which is a significant value indicating that there is a clear response to the structural capital field at Al-Ahliyya Amman University, and the total relative weight of the field was equal to ( $80.8 \%$ ) and this result indicates that the structural capital at the university came to a high degree, and it becomes clear that the highest paragraph is Paragraph No. (3) which states (There is a specific job description for the tasks, duties and responsibilities required of the university employee) and obtained approval to a large degree and with relative weight $(85.6 \%)$ and a significance level less than (0.05). Therefore, this paragraph is considered a statistical function, like the rest of the paragraphs in this field.

The third question: What is the role of relational capital in achieving competitive advantage in Al-Ahliyya Amman University?

Table 5. The arithmetic mean, standard deviation, and estimates of the study sample individuals and t-test for the capital relational

\begin{tabular}{|c|c|c|c|c|c|c|c|}
\hline $\mathbf{N}$ & $\begin{array}{c}\text { Paragraphs of } \\
\text { independent variables } \\
\text { Relational capital }\end{array}$ & $\begin{array}{c}\text { Arithmetic } \\
\text { Mean }\end{array}$ & $\begin{array}{l}\text { Standard } \\
\text { Deviation }\end{array}$ & $\begin{array}{c}\text { Relative } \\
\text { weight of the } \\
\text { sample } \\
\text { estimates }\end{array}$ & $\begin{array}{l}\text { t test } \\
\text { value }\end{array}$ & Sig. & Rank \\
\hline 1 & $\begin{array}{l}\text { The university } \\
\text { administration encourages } \\
\text { teamwork and a team } \\
\text { spirit methods. }\end{array}$ & 4.31 & 0.982 & $\% 86.2$ & 17.19 & 0.000 & 2 \\
\hline 2 & $\begin{array}{l}\text { University work teams } \\
\text { contribute to creating } \\
\text { innovative ideas. }\end{array}$ & 4.42 & 0.881 & $\% 88.4$ & 18.30 & 0.000 & 1 \\
\hline 3 & $\begin{array}{l}\text { The university } \\
\text { administration works to } \\
\text { provide a stimulating } \\
\text { environment to the } \\
\text { development of positive } \\
\text { communications and } \\
\text { networking among all its } \\
\text { employees. }\end{array}$ & 4.08 & 0.874 & $\% 81.6$ & 14.64 & 0.000 & 4 \\
\hline 4 & $\begin{array}{l}\text { University employees } \\
\text { have distinguished social } \\
\text { relations with workers in } \\
\text { competing universities. }\end{array}$ & 3.96 & 0.931 & $\% 79.2$ & 11.13 & 0.000 & 5 \\
\hline 5 & $\begin{array}{l}\text { The social relations of } \\
\text { university employees are } \\
\text { characterized by respect } \\
\text { and appreciation with } \\
\text { officials and workers in } \\
\text { government institutions. }\end{array}$ & 4.19 & 0.866 & $\% 83.8$ & 16.33 & 0.000 & 3 \\
\hline & Total & 4.20 & 0.744 & $\% 84.0$ & 15.92 & 0.000 & \\
\hline
\end{tabular}


Table 5 shows that the value of $(t=15.92) \mathrm{T}$ test and the value of the calculated test significance was $(\mathrm{sig}=0.000)$, which is a significant value indicating that there is a clear response to the field of relational capital at Al-Ahliyya Amman University, and the total relative weight of the field was equal to $(84.0 \%)$ This result indicates that the relational capital at the university came to a high degree, and it is clear that the highest paragraph is paragraph No. (2), which states (The work teams at the university contribute to creating creative and innovative ideas) and obtained approval to a large degree and with relative weight $(88.4 \%)$ and a significance level less than $(0.05)$. Therefore, this paragraph is considered a statistical function, like the rest of the paragraphs in this field. The fourth question: What are interviewees' perceptions of the level of achieving competitive advantage at Al-Ahliyya Amman University?

Table 6. the arithmetic mean, standard deviation and estimates of the study sample individuals and the t-test of the dependent variable Achieving the competitive advantage

\begin{tabular}{cccccccc}
\hline N & $\begin{array}{c}\text { Paragraphs of the } \\
\text { dependent variable } \\
\text { (achieving competitive } \\
\text { advantage) }\end{array}$ & $\begin{array}{c}\text { Arithmetic } \\
\text { Mean }\end{array}$ & $\begin{array}{c}\text { Standard } \\
\text { Deviation }\end{array}$ & $\begin{array}{c}\text { Relative } \\
\text { weight of the } \\
\text { sample } \\
\text { estimates }\end{array}$ & $\begin{array}{c}\text { t test } \\
\text { value }\end{array}$ & Sig. & Rank \\
\hline
\end{tabular}

The university is Continued diversifying

1 and developing study plans and university services.

The university adopts

2 international quality standards in providing educational services.

The university administration seeks to overcome the difficulties

3 in order to provide the required service to the public of customers with high quality.

The university administration is interested in focusing on implementing international quality standards and considering them as a basis for work.

The university is keen to 5 implement and ensure quality in all its services.

\section{Total for the quality of education}

University staff seek to find new, more effective

6 ways to face developments and changes.

The university 7 administration is working to change the means of

\section{Quality of education}

$\begin{array}{llllll}3.94 & 0.982 & \% 78.8 & 12.99 & 0.000 & 4\end{array}$

1.030

$\% 86.0$

$14.93 \quad 0.000$

$\begin{array}{llllll}4.26 & 0.977 & \% 85.2 & 14.29 & 0.000 & 2\end{array}$

$\begin{array}{llllll}4.15 & 0.876 & \% 83.0 & 13.13 & 0.000 & 3\end{array}$

4.11

0.629

$\% 82.2$

$12.94 \quad 0.000$

Flexibility and responsiveness

$\begin{array}{llllll}4.31 & 1.039 & \% 86.2 & 15.23 & 0.000 & 2\end{array}$

4.40

1.131

$\% 88.0$

$\begin{array}{lll}17.34 & 0.000 \quad 1\end{array}$ 
work to face the urgent challenges.

The university administration believes

8 that change is a natural phenomenon that they can adapt to it.

The university seeks to 9 respond quickly to the needs and aspirations of students.

The university administration works to 10 adapt and respond quickly to seize the opportunities available in the external environment.

\section{Overall score for Flexibility and responsiveness}

The university is keen to

11 provide creative and innovative services.

The university provides

all facilities to encourage its employees to be creative.

The university is inspired by creative and innovative

13 ideas by communicating with students, their families and listening to their suggestions.

The university provides material and moral

14 incentives for innovation ideas.

University officials

15 possess a high ability to perceives future ideas.

Total degree of innovation

The dependent variable as a whole

$$
0.874
$$

$\% 77.0$

14.110 .000

5

$\begin{array}{llllll}4.02 & 0.793 & \% 80.4 & 14.32 & 0.000 & 4\end{array}$

$\begin{array}{llllll}4.14 & 0.994 & \% 82.8 & 15.90 & 0.000 & 3\end{array}$

4.16

0.647

$\% 83.2$

16.620 .000

\section{Innovation}

1.012

$\% 85.8$

$11.44 \quad 0.000$

2

$\% 82.0$

$11.27 \quad 0.000$

3

$\begin{array}{llllll}4.33 & 0.971 & \% 86.6 & 12.13 & 0.000 & 1\end{array}$

3.80

0.886

$\% 76.0$

$10.23 \quad 0.000$

5

3.87

0.798

$\% 77.4$

$10.88 \quad 0.000$

4

$\begin{array}{llllll}4.08 & 0.663 & \% 81.6 & 11.08 & 0.000 & - \\ 4.12 & 0.686 & \% 82.4 & 12.13 & 0.000 & -\end{array}$

As shown in table 6 (Education Quality) that the value of T.Test reached $(\mathrm{t}=12.94)$, and the value of the calculated test significance reached $(\mathrm{Sig}=0.000)$, which is a significant value indicating that there is a clear response to the field of education quality as one of the dimensions of competitive advantage In Al-Ahliyya Amman University, the relative weight of this field was $82.2 \%$, which indicates that the quality of education at the university was high. It is clear that the highest paragraph is Paragraph No. (2), which states (the university adopts international quality standards in providing educational services) and obtained approval to a large degree with a relative weight of (86.0\%) and a significance level less than (0.05). Therefore, this paragraph is considered a statistically significant like the rest Paragraphs of this field.

Table 6 also shows also (Flexibility and responsiveness) that the value of T.Test reached $(t=16.62)$, and the value of 
the calculated test significance reached $(\mathrm{Sig}=0.000)$, which is a significant value indicating that there is a clear response to the dimension of flexibility at Al-Ahliyya Amman University, and the relative weight of the total field was equal to $(83.2 \%)$, which indicates that the process of flexibility and response in the university came with a high degree. It is clear that the highest paragraph is Paragraph No. (7) which states (The university administration is working to change the means of work to face the urgent challenges) and obtained approval to a large degree and with a relative weight of $(88.0 \%)$ and a significance level less than $(0.05)$. Therefore, this paragraph is considered a statistical function. Like the rest of the paragraphs of this field.

It also appears from Table 6 (Innovation) that the value of $\mathrm{T}$ test reached $(\mathrm{t}=11.08)$, and the value of the calculated test significance reached $(\mathrm{Sig}=0.000$ ), which is a significant value indicating that there is a clear response to the creativity dimension at Al-Ahliyya Amman University. The relative weight of the total field was equal to (81.6\%), which indicates that innovatin at the university came with a high degree. It is clear that the highest paragraph is Paragraph No. (13) which states (The university is inspired by creative and innovative ideas by communicating with students and their families and listening to their proposals) and obtained approval to a large degree with a relative weight of $(86.6 \%)$ and a level of significance less than (0.05). This paragraph is a statistical function like the rest of the paragraphs in this field.

\section{Analysis of study questions and hypothesis testing:}

The main question: What is the role of intellectual capital with its components (combined) in achieving competitive advantage in Al-Ahliyya Amman University?

\section{From this question, the following hypothesis is formulated:}

There is no statistically significant role at the level of significance $(\alpha=0.05)$ for intellectual capital with its components (human capital, structural capital, and relational capital) in achieving competitive advantage in its dimensions (quality of education, flexibility and responsiveness, and innovation) at Al-Ahliyya Amman University.

To test this hypothesis, multiple linear regression analysis was use.

Table 7. Results of multiple linear regression analysis of intellectual capital with its components in achieving competitive advantage at Al-Ahliyya Amman University

\begin{tabular}{cccccccccc}
\hline $\begin{array}{c}\text { Dependent } \\
\text { variable }\end{array}$ & $\mathbf{R}$ & $\mathbf{R}^{2}$ & $\mathbf{F}$ & $\begin{array}{c}\text { Freedom } \\
\text { degree }\end{array}$ & Sig. & $\begin{array}{c}\text { Independent } \\
\text { variables }\end{array}$ & $\boldsymbol{\beta}$ & $\begin{array}{c}\mathbf{t} \\
\text { value }\end{array}$ & Sig. \\
\hline Competitive & 0.813 & 0.661 & 161.65 & 627 & 0.000 & $\begin{array}{c}\text { Structural } \\
\text { capital }\end{array}$ & 0.540 & 16.37 & 0.000 \\
advantage & & & & & & $\begin{array}{c}\text { Human } \\
\text { Relational } \\
\text { capital }\end{array}$ & 0.497 & 14.19 & 0.000 \\
\hline
\end{tabular}

The main hypothesis was tested at the level of significance (0.05), and the results were shown in Table (7) according to the following:

- The tabular $\mathrm{F}$ value was extracted to compare it with the calculated $\mathrm{F}$, and it turns out that valued of the calculated $\mathrm{F}$ (161.65) is greater than the tabular $\mathrm{F}$ value (2.65) and it proves the significance of the model used in the regression analysis.

- The significance level of the test was compared with the level of significance adopted in the study to indicate the existence of a role of influence on the dependent variable (competitive advantage). The above table No. (7) shows that the significance level for $(F)$ reached $(0.000)$, which is less than the level of significance adopted in the study (0.05). Thus, we reject the null hypothesis and accept the alternative hypothesis. "There is a role of statistical significance at the level of significance $(\alpha=0.05)$ of intellectual capital with its components (human capital, structural capital, and relationship capital) in achieving competitive advantage in its dimensions (quality of education, flexibility and responsiveness, and innovation) at Al-Ahliyya Amman University.

- The value of $\mathrm{R}$ is inferred to indicate the existence of a correlation between the independent variables and the dependent variable, and through Table No. (7) above it was found that the value of the correlation is equal to (0.813), which indicates a strong positive correlation between the components of intellectual capital and achieving competitive advantage at Al-Ahliyya Amman University. 
- The results proved that there is an explanatory capacity for the independent variables combined (human capital, structural capital, and relational capital) on the dependent variable (achieving competitive advantage) and its value $(66.1 \%)$, and it was inferred from the value of the determination coefficient $(\mathrm{R} 2=0.661)$.

\section{Results of the Study}

1. It is clear to us through the results of Table No. (2) that the majority of the sample items are males at a rate of $(61.4 \%)$, but that the percentage of females reached (38.6) and that this percentage for females indicates that the university encourages the attract of female workers on the basis that the participation of women At work, it is considered an important developmental requirement in the comprehensive development process. Likewise, the success of Jordanian women in reaching leadership positions and their effective contribution to public life and higher education institutions are among the most important aspects of gender justice. The majority of the workers at the researched university are young people whose age ranges between (31 to 50 years) amounted to more than (60\%), and that more than $(61 \%)$ of the sample members have higher university degrees (Master and $\mathrm{PhD}$ ), and it was found that the majority of The sample members who have experience of (6-16 years) amounted to about (69\%).

2. The study showed that the components of intellectual capital (combined) have achieved different levels at AlAhliyya Amman University as follows:

- The field of human capital achieved a high response degree (4.09) with a relative weight (81.8\%).

- The structural capital field achieved a high degree of response as well, reaching (4.04) with a relative weight $(80.8 \%)$.

- The field of relational capital also achieved a high response degree (4.20) with a relative weight (84.0\%).

3. The study concluded that there is a positive, influential relationship for intellectual capital with its components (combined) in achieving competitive advantage at the university, as the value of the Pearson correlation coefficient (R) for this relationship is more than $(81 \%)$ and with a significant significance $(0.000)$ less than the significant $(0.05)$ This result intersects with the study of (Raed et al., 2020), (Saqer et al., 2019) and (Nazem et al., 2018).

4. The competitive advantage achieved a high degree of response from the study sample amounting to (4.12) and with a relative weight of more than $(82 \%)$. This is an indication of the study sample's keenness to achieve a competitive advantage for Al-Ahliyya Amman University. 2020), (Matthew et al., 2020), and (Asante \& Adu-Damoah, 2018).

\section{Recommendations}

According to the conclusions and findings of this study, I have concluded the following recommendations:

1) The necessity of dealing with intellectual capital as a major and strategic resource for the university and considering it the real wealth that guarantees universities the ability to adapt to changes and to achieve a competitive advantage.

2) Encouraging cooperation and establishing more strategic alliances in order to contribute to to promote the relational capital at the university.

3) Emphasis on attracting competencies from the labor market as a means to achieve a competitive advantage in human capital at the university.

4) The necessity for the university to support and encourage creativity through innovative solutions and ideas presented by employees and to put them into practice.

5) Motivating and encouraging employees to create and innovate to ensure the success of university services and improve them according to a specific and clear system.

6) The necessity to build a positive organizational culture to develop social cohesion and strengthen relations between employees, which contributes to creating synergies among employees.

7) Adopting real practices for teamwork methods, promoting a spirit of teamwork, and supporting a love of belonging to work through improving the physical and social work environment at the university.

8) The study recommends the establishment of a unit called the "Creative and Innovative Business Unit" that is directly linked to the presidency of the university, and is responsible for all creative works and preserving the rights of creators and their creative works.

9) Encouraging workers to develop their abilities and personal skills, and allow them to innovate and create. 
10) The necessity of developing a strategic curriculum for the development of workers in respect to their skills, knowledge and human relations on an ongoing basis within the framework of continuous education for them in order to improve their performance and maintain a high level of knowledge in a way that makes them more responsive to environmental changes.

11) The study recommends conducting more studies and research on intellectual capital and its role in other dependent variables that were not taken into consideration by this study.

\section{References}

Akben-Seluck, E. (2016). Factors Affecting Firm Competitiveness: Evidence From an Emerging Market, International Journal of Financial Studies, Vol (4), Iss (2). https://doi.org/10.3390/ijfs4020009

Al Zahrani, A. A., Zamil, A. M., Areiqat, A. Y., \& Alsalhi, N. (2012). The impact of antecedents supporting organizational innovation on employees' psychological empowerment: An empirical study of Saudi and Jordanian industrial corporations. African Journal of Business Management, 6(24), 7329-7343. https://doi.org/10.5897/AJBM11.3032

Alheet, A., Adwan, A., Areiqat, A., Zamil, A., \& Saleh, M. (2020). The effect of leadership styles on employees' innovative work behavior. Management Science Letters, 11(1), 239-246. https://doi.org/10.5267/j.msl.2020.8.010

Al-Shimi, Ashraf Abd AL Rahman (2011). Knowledge Management and Intellectual Capital, University Knowledge House for Printing and Publishing, Cairo, Egypt.

Areiqat, A., \& Zamil, A. (2019). How Applying Soft Lean Components Can Contribute to Reducing Costs in the Service Sector: The Case of Al-Ahliyya Amman University. Int. J Sup. Chain. Mgt Vol, 8(5), 57.

Areiqat, A. Y., Hamdan, Y., Zamil, A.M., Omar, Horani, \& Al-Khoury, A. F. (2020). Culture and Leadership Are Simply Two Sides of the Same Coin. International Journal of Innovation, Creativity and Change, 13(4), 123147.

Areiqat, A. Y., Zamil, A. M., Fathi, A., Ahmad, M. M., \& Abushaar, H. M. (2020). The Concept of Governance in Universities: Reality and Ambition. International Journal of Innovation, Creativity and Change, 13(1), 951-969

Areiqat, Ahmad Abdelhadi, Tawfiq Al-Bazaieh, Sakher., \&Abu Rumman, Ayman. (2019). The effect of corporate social responsibility in achieving competitive advantage at Jordanian Aviation Companies. International journal of supply chain management, Volume. 8, Issue. 2.

Areiqat, Ahmad \& Jaradat, Nasser. (2012). The impact of human capital on the performance of Palestinian companies, Arab Journal of Management, Vol. 1, Issue. 32.

Areiqat, Ahmad, Hamdan, Yacoub, Zamil, Ahmad \& Aldabbagh, Issam. (2020). True Workplace Diversity: A Key Ingredient for Business Success, Regardless of the Industry or Company Size. Journal of Talent Development and Excellence, Volume 12, Issue 2, 2304-2314.

Areiqat, Ahmad. (2019). Intellectual Capital in light of Creativity and Competitiveness; Overview of Organizations' Intangible Assets. The Journal of Social Sciences Research, Vol. 5, Issue. 7.

Asante Boakye Elijah \& Adu-Damoah Millicent (2018). The Impact Of A Sustainable Competitive Advantage On A Firm's Performance: Empirical Evidence From Coca-Cola Ghana Limited, Global Journal of Human Resource Management, Vol.6, No.5, 30-46.

Aymen Raheem Abdulaali (2018). The Impact of Intellectual Capital on Business Organization, Academy of Accounting and Financial Studies Journal, Vol (22), Issue (6).

Elena, Pelinescu (2015). The Impact of Human Capital on Economic Growth, Procedia Economics and Finance, Vol (22), 184-190. https://doi.org/10.1016/S2212-5671(15)00258-0

Gogan L. M., \& Duran, D. C. (2014). Intellectual Capital Management - A new Model. Practical Application of Science, Vol (2), Iss (6), 57-64.

IMD, (2020). Competitiveness Ranking 2020, imd.org.

Jamal, A. Nazari \& Irene M. Herremans (2017). Measuring Intellectual Capital Components, Journal of Intellectual Capital, Vol (8), Iss (4). https://doi.org/10.1108/14691930710830774 
Januškaite, V., \& Užiene, L. (2018). Intellectual Capital as a Factor of Sustainable Regional Competitiveness, Sustainability, vol (10). https://doi.org/10.3390/su10124848

Kianto, A., Andreva, T., \& Pavolv, Y. (2013). The Impact of Intellectual Capital Management on Company Competitiveness and Financial Performance, Journal Knowledge Management Research \& Practice, Vol (11), Iss (2), 112-122. https://doi.org/10.1057/kmrp.2013.9

Kozera-Kowalska, M., \& Baum, R. (2018). Measurement of intellectual capital in agricultural enterprises: A case study in Poland. In Proceedings of the Economics and Finance Conferences, International Institute of Social and Economic Sciences, Rome, Italy, 209-220. https://doi.org/10.20472/EFC.2018.010.015

Magdalena Kozera-Kowalska (2020). Intellectual Capital: ISVA, the Alternative Way of Calculating Creating Value in Agricultural Entities-Case of Poland, Journal sustainability, Vol (12), 2-19. https://doi.org/10.3390/su12072645

Magdalena, K. Kowalska, (2020). Intellectual Capital: ISVA, the Alternative Way of Calculating Creating Value in Agricultural Entities-Case of Poland, Sustainability 2020, Vol (12). https://doi.org/10.3390/su12072645

Margareta, R. Tanasa (2015). Intellectual Capital a Strategic Factor of Socio-Economic Development of Regions and Countries, Procedia Economics and Finance, 27(2015), 369-374. https://doi.org/10.1016/S2212-5671(15)010084

Matthew Kwaw Somiah, Clinton Aigbavboa \& Wellington Didibhuku Thwala (2020). Rethinking the Attributes for Competitive Advantage of Indigenous Construction Firms in Developing Countries: A Ghana Study, International Journal of Construction Education and Research. https://doi.org/10.1080/15578771.2020.1739179

Meihami, B., \& Meihami, H. (2014). Knowledge Management a Way to Gaina Competitive Advantage in Firms, International Letters of Social and Humanistic Sciences, Vol (14), 80-91. https://doi.org/10.18052/www.scipress.com/ILSHS.14.80

Michael E. Porter (1985). Competitive Advantage: Creating and Sustaining Superior Performance, Simon \& Schuster, U.S.A.

Nazem M. M. Malkawi, Kalid Al Omari \& Azmi Halasa (2018). Intellectual Capital as a Core Competency for Competitive Advantage: A Case Study, Journal of Digital Information Management, Volume (16), Number (4), 192-202. https://doi.org/10.6025/jdim/2018/16/4/192-202

Raed Kareem Kanaan, Ulya Nawaf Obeidat, Bader Yousef Obeidat, Mohammad Orsan Al-Zu'bi \& Mohammd Abuhashesh (2020). The Effect of Intellectual Capital on Competitive Advantage in the Jordanian Telecommunication Sector, Journal of Business \& Management, Vol 8, No 1, 1-19. https://doi.org/10.25255/jbm.2020.8.1.1.19

Salameh, A., \& Zamil, Z. (2020). The effects of reward systems and organizational structure on tacit knowledge sharing. Management Science Letters, 10(10), 2229-2236. https://doi.org/10.5267/j.msl.2020.3.013

Saqer Sulimas Al -Tahat, Matarneh, Alaa Jaber Matarneh \& Osama Abdul Moneim Ali (2019). The Impact of the Intellectual Capital of the University Administration in Achieving the Quality of Education, International Journal of Economics and Finance, Vol (11), No (2), 137-154. https://doi.org/10.5539/ijef.v11n2p137

Scafarto, V., Ricci, F., \& Scafarto, F. (2016). Intellectual capital and firm performance in the global agribusiness industry: The moderating role of human capital. J. Intellect. Cap. Vol (17), 530-552. https://doi.org/10.1108/JIC11-2015-0096

Sungmin Kang \& Youn Kue Na (2020). Effects of Strategy Characteristics for Sustainable Competitive Advantage in Sharing Economy Businesses on Creating Shared Value and Performance, Journal sustainability, Vol (12), 2-21. https://doi.org/10.3390/su12041397

\section{Copyrights}

Copyright for this article is retained by the author(s), with first publication rights granted to the journal.

This is an open-access article distributed under the terms and conditions of the Creative Commons Attribution license (http://creativecommons.org/licenses/by/4.0/). 